\title{
Who Is Legitimating Whom? On Justifying Buddhism's Place in the Body Politic
}

\author{
Sem Vermeersch
}

In this chapter I revisit the idea of legitimacy and question whether or not it is really a useful concept. Insofar as possible, I take a broad look across East Asian states in order to see how well the concept can be applied across various times and dynasties. However, for practical reasons I restrict myself mostly to medieval China and medieval Korea (Koryŏ (918-1392, 高麗國)), the areas I am most familiar with.

Following the publication of The Power of the Buddhas, ${ }^{1}$ there have not been many studies that attempt a conceptual analysis of power relations between the state and religious communities in pre-modern East Asian (or Central Asian) societies. ${ }^{2}$ Valuable work has, of course, been done, and I will turn to some of it later. However, what strikes me is that the most innovative research in terms of Buddhism's working at the level of the seats of power, has been done in the fields of art and archeology — or perhaps better, the material culture of Buddhism. I refer especially to the richly challenging work by Eugene Wang, as well as the many studies of relics, dhäranīs, and other material remnants, tangible reminders of what has been termed 'Buddhist on the ground' (or perhaps 'in the ground').

Of course, texts are ultimately also material, but they have been largely treated in a disembodied way, as ideas rather than practices. Thus, we seem to

1 Sem Vermeersch, The Power of the Buddhas: The Politics of Buddhist During the Koryŏ Dynasty, 918-1392 (Cambridge: Harvard University Asia Center, 2008).

2 I am fully aware of the potential pitfalls of designating Buddhism, Daoism, or other traditions in premodern East Asia as "religious," which would imply the recognition of the secular-religious dichotomy. Although what we would now designate "religious" structures or ideas were subsumed by the state in imperial China, Buddhism nevertheless became at times almost regarded as an entity separate from the state and always retained some of that "otherness." See Robert F. Campany, "Chinese History and Writing about 'Religion(s)': Reflections at a Crossroad," in Dynamics in the History of Religions between Asia and Europe: Encounters, Notions, and Comparative Perspectives, ed. Volkhard Krech and Marion Steinicke (Leiden and Boston: Brill, 2012), 273-294. I am indebted to one of the anonymous reviewers for pointing me to this work. 
have quite different streams of scholarship dealing with Buddhist legitimation in East Asia: with more traditional legitimation studies based on texts on the one hand, and more innovative studies dealing with personal devotion, practice, and aspiration based on archeological evidence, or on hitherto neglected genres of text, on the other. So, one of the main purposes of this chapter is to connect these two streams and see whether we are really dealing with mutually exclusive universes of meaning, or whether there is a common ground, an overlap, and hopefully a synergy between the two that may lead to new insights.

I start by revisiting Max Weber (1864-1920) and his concept of legitimation, and elucidate how it has evolved over time, and add some reflections on more recent theories of power. Then, considering some of these reflections on the concept of legitimation, I take a broad overview of the state of scholarship on the problem of legitimation in East Asia. Following that, I move back to my own area of expertise, i.e. Korean Buddhism, and revise some of my own conclusions regarding the legitimating role of Buddhism, taking into account recent research on Chinese Buddhism, but also research on religion and power in other contexts.

Let us start by recalling in brief how Weber conceived of legitimation and how it became one of his most well-known theories. Regrettably, we can only give a very succinct overview, one that does not really do him justice. Weber is not exactly easy to pin down or summarize. Moreover, his last work, the "Theory of Social and Economic Organization (Wirtschaft und Gesellschaft)," was not finalized at the time of his death. It is precisely this work that contains his most developed ideas on the subject.

As is well known, his is a theory of political authority, one that seeks to explain how authority is established and maintained. While many may consider coercion and military power to be crucial, according to Weber, to maintain authority, those who are governed must accept that it is right and proper that they are ruled by those in authority; in other words, authority is much more effective when it is generally accepted rather than resisted. In that case, we can say that an authority or government is considered 'legitimate.' Weber famously distinguished three kinds of rationalizations on the basis of which power can be accepted as legitimate: 
1. Power can be accepted on rational grounds, resting on the belief that patterns of normative rules are 'legal' and that those in authority have the right to enforce those rules;

2. it can be accepted on traditional grounds, i.e. an established belief in the sanctity of immemorial traditions and the legitimacy of the status of those exercising authority under them; and

3. it can be accepted on charismatic grounds, or devotion to the specific and exceptional sanctity, heroism, or exceptional character of an individual person, and of the normative patterns or order revealed or ordained by him. ${ }^{3}$

Since Weber is speaking universally, i.e. not limited to the modern or premodern era, nor to democratic or autocratic systems, his theory is still eminently applicable and attractive. Yet at the same time, its general nature covers over many lacunae. I will cite two critics in particular who have laid bare the limitations of Weber. The first, José Merquior (1941-1991), is arguably among the sharpest critics. He points out that Weber's theory is subjectivist, in that it searches for the psychological motivations for accepting authority. In this sense, it is really about the individual's belief in the rightness to rule of those in authority. Weber's theory is based on the assumption that certain beliefs exist among both rulers and ruled. ${ }^{4}$ However, Merquior points out that Weber neglects the view from below. In other words, he is too ruler-centered.

Jürgen Habermas, however, points to other passages in Weber's work that show his awareness of this problem. From a Marxist (class analysis) point of view, class societies are based on the "privileged appropriation of socially produced wealth." 5 In other words, 'legitimate' authorities use their position of authority to appropriate resources from others, or to assert power over them. Even though those who are thereby disadvantaged may acquiesce to the norms that justify this, this is by no means a case of blind faith.

The factual recognition of such norms does not, of course, rest solely on belief in their legitimacy by those affected. It is also based on fear of, and submission to, indirectly threatened sanctions, as well as on simple compliance engendered by the individual's perception of his own powerlessness and the lack of alternatives open to him (that is, by his own fettered imagination). ${ }^{6}$

3 Max Weber, The Theory of Social and Economic Organization, trans. A.M. Henderson and Talcott Parsons (Glencoe, Ill.: The Free Press, 1947), 328.

4 José Merquior, Rousseau and Weber: Two Studies in the Theory of Legitimacy (London: Kegan Paul, 1980), 6-7.

5 Jürgen Habermas, Legitimation Crisis, trans. Thomas McCarthy (Boston: Beacon Press, 1975), 96.

6 Ibid. 
Weber's own words are, if anything, even more laconic:

It is by no means true that every case of submissiveness to persons in positions of power is primarily (or even at all) oriented to this belief [in the legitimacy of the system]. Loyalty may be hypocritically simulated by individuals or by whole groups on purely opportunistic grounds, or carried out in practice for reasons of material self-interest. Or people may submit from individual weakness and helplessness because there is no acceptable alternative. ${ }^{7}$

Still, to him this does not diminish the fact that legitimacy is still to a large degree 'valid.' Habermas points out, however, that this validity is not undisputed. Legitimation should still bear a relation to truth, but how to define 'truth' and how it disrupts the legitimation system is not so clearly explained. ${ }^{8}$ The important point to take away from this is that what may appear to be legitimation may, in fact, simply be a set of conventions to which both rulers and ruled adhere but not necessarily with much conviction or substance; paraphrasing Weber's theory of the routinization of charisma, it may be that legitimation may also be routinized, ergo gradually losing its 'vitality.'

Arguably the biggest challenge to the ideas of Weber, and the biggest shift in looking at power relations, is the French philosophical school of the 196os and 1970s, usually labelled 'postmodern.' According to most postmodern theorists, power derives neither from military might nor from a legitimating ideology, but is constructed impersonally through discourse. In other words, it works through the persuasive force of language. As such, this conception of power might be seen as a refinement of Weber's ideas (legitimation through the manipulation of language), but importantly it eschews (even destroys) the notion of 'ideology'. In this sense it corresponds with Merquior's critique, even though he is known to have distanced himself vociferously from Michel Foucault (1926-1984). ${ }^{10}$ According to Foucault and others of the postmodern school, there is no core set of ideas or norms that radiate outwards, but rather

$7 \quad$ Habermas, Legitimation Crisis, 96; quoting from Max Weber, "The Types of Legitimate Domination," in Economy and Society. An Outline of Interpretative Sociology Volume 1, ed. Guenther Roth and Claus Wittich (New York: Bedminster Society, 1968), 214.

See Habermas, Legitimation Crisis, 9. His work was meant as a kind of template for a larger project, and hence some parts appear underdeveloped. However, in its brevity, it is eminently accessible. I have managed to survey the field, however, it appears that Weber's ideas are generally held to be valid among sociologists.

See José Merquior, Foucault (Berkeley: University of California Press, 1985). 
a manipulation of narratives and images that are largely shared (from a common language until a paradigm shift erupts).

However, the problem for me lies in making sense of what Foucault is exactly trying to argue. One important problem is that he seems to be making the case (very simply put) that biopolitics and self-surveillance (or other forms of surveillance) are modern constructs, replacing older forms of coercion that are violent (torture, incarceration, killing, etc.). Whereas self-discipline was used in antiquity by elites who wanted to set themselves apart from those considered inferior, in the modern period universalised self-discipline makes the individual susceptible to being controlled. As many have pointed out, however, it is dangerous to apply what are essentially European categories to other contexts; in his study of courtly culture in early medieval India, for example, Daud Ali points to the fact that Foucalt's method is not well suited to normative historical and sociological enquiry, and cannot simply be applied to the Indian context.11

Moreover, applying Foucault's ideas without excessive use of jargon and passive voice constructions is not easy. Still, the fact that this legacy can be useful for refining the question of religious legitimation is made clear in a short essay by Anne Blackburn, a review of Azfar Moin's The Millenial Sovereign. Reflecting on this book, she identifies the most nefarious preconceptions that emerged in the fields of comparative theology and religion during the eighteenth and nineteenth centuries: "The heart of 'religion' is 'doctrine.' 'Religion' is not-politics and private."12 Indeed, our tendency to apply the modern statereligion model can lead to many distortions, and it is worth spelling out the two fallacies still haunting many studies that she identifies here so succinctly. The first is the supposition that there is a direct link between doctrine and legitimation, i.e. that there is an ideological program that is somehow put into effect. While this may not be ruled out, as I hope to make clear in this chapter, legitimation strategies are in most cases not based on specific doctrinal texts. The second fallacy concerns the assumption that 'religion' and 'state' were mostly clearly delineated, the one concerning private affairs and the other political affairs. Again, while in East Asia the state, often identified with Confucianism, in its turn tried to keep Buddhism to the domestic realm, the boundaries were constantly in flux, with private religious beliefs often taking center stage in political discussions.

Daud Ali, Courtly Culture and Political Life in Early Medieval India (Cambridge: Cambridge University Press, 2004), 9-11.

12 Ann, Blackburn, "Buddhist Technologies of Statecraft and Millenial Moments," History and Theory 56.1 (2017): 72 . 
In her essay-review, Blackburn tries to show how the end-of-dharma soteriology in the Asian subcontinent spurred rulers to act in often very different ways, depending on local factors, circumstances, and personalities. The point appears to be that the model of the Wheel-Turning King (Skt. cakravartin, Chin. zhuanlun wang 轉輪王) as an ideal of rulership was employed creatively in ad-hoc texts; one of her arguments concerns the need to look beyond standard texts and include a wide variety of texts circulating among the people. However, the conclusions are actually rather conventional and coincide remarkably well with what we see in East Asia, where the end of the dharma is often invoked by rulers to strengthen their hold over Buddhism. Still, Azfar Moin's own arguments about sacred kingship among the Mughals seem to be relevant for my own project and should help us towards a broader and more flexible understanding of legitimation: "The dominant experience of sacred authority for most people-elite or common - was concrete and embodied rather than abstract and textual."13

\section{Legitimation across the Asian Continent}

In his introduction to The Middle Kingdom and the Dharma Wheel: Aspects of the Relationship Between the Buddhist Samgha and the State in Chinese History, Thomas Jülch has already provided an admirable digest of relevant research of the past decades on the question of how Buddhism may or may not have helped to legitimate temporal power in Chinese dynasties. However, his focus is somewhat wider than the concept of legitimation, since he looks at the whole spectrum of relations between the Buddhist state and various Chinese polities, including negative aspects such as state repression of Buddhism. In the second section of this introduction, then, he gives an overview of how "Buddhism [is used to] ideologically strengthen the emperor."14 Here Jülch looks at six ways of making the emperor "soteriologically significant" by giving him a place in the Buddhist pantheon of world saviors:

1. the ruler could be hailed as a Buddha;

2. he could be identified as a cakravartin, the Wheel-Turning King who based his legitimacy on the fact that he spread the dharma;

13 Azfar Moin, The Millennial Sovereign. Sacred Kingship and Sainthood in Islam (New York: Columbia University Press, 2014), 8.

14 Thomas Jülch, "Introduction," in The Middle Kingdom and the Dharma Wheel: Aspects of the Relationship between the Buddhist Samgha and the State in Chinese History, ed. Thomas Jülch (Leiden: Brill, 2016), 7-14. 
3. in the context of end-of-dharma soteriology, the king could also be presented as savior and guardian of the dharma at a time when monks were becoming inevitably corrupt;

4. he could be associated or identified with the future Buddha Maitreya;

5. emperors could be identified as reincarnations of the bodhisattva Mañjuśrī, which happened mainly in the Yuan (1279-1368, 元) and Qing (1644-1912, 清) dynasties; and

6. emperors, or in this case empress dowager Cixi (1835-1905, 慈禧), could be identifed with other bodhisattvas, in this case Avalokiteśvara. ${ }^{15}$

Besides the fact that legitimation does not only take place through the elevation/deification of the ruler (pace Weber, this is only the charismatic aspect, but there are also the rational and traditional aspects of legitimation, which do not necessarily focus on the ruler alone), one might object that the division is somewhat arbitrary, since some of the categories are only variations of the sort 'identifying with a Buddha/bodhisattva.' Another problem is that many of the cases given are unique examples, such as the identification with Maitreya, which only happened under the Tuoba rulers of the Northern Wei (386-535, 北魏); later rulers seem to have shunned such identification because of its association with millenarian cults and hence disorder. ${ }^{16}$ But a more fundamental problem is that even for individual rulers, it is difficult to put them in any particular category. For example, Jülch identifies Sui Wendi (r. 581-604, 隋文帝) as belonging to the cakravartin model, but as Chen Jinhua has shown, Emperor Wen identified himself both as bodhisattva and as cakravartin. ${ }^{17}$

This should prompt us to reflect on whether there is really an ideological template that was followed. Recent research by Antonello Palumbo points to the difficulty in locating such models; as he points out, the Indian texts about Buddhist monarchs are "contextless," so that we do not know if they were followed, while on the Chinese side, rulers

fashion their own experiments of Buddhist statecraft in ways that it may be tempting to explain as sheer bricolage $[\ldots .$.$] We would have then,$

15 Thomas Julch, "Introduction." It is somewhat disappointing that, apart from the introduction, none of the chapters in this edited volume attempt any more systematic or theoretically grounded analysis of the legitimation problem.

Antonino Forte, Political Propaganda and Ideology in China at the End of the Seventh Century: Inquiry into the Nature, Author, and Function of the Tunhuang Document S. 6502, Followed by an Annotated Translation (Kyoto: Scuola Italiana di studi sull'Asia orientale, 2005), 223-242 (esp. 225).

17 Jinhua Chen, Monks and Monarchs, Kinship and Kingship. Tanqian in Sui Buddhism and Politics (Kyoto: Scuola Italiana di Studi sull'Asia Orientale, 2002), 114. 
models without real rulers to follow them on one side, and rulers without models on the other. ${ }^{18}$

Nevertheless, Palumbo shows how Indian sources did in fact inspire at least the Chinese samgha to change its attitudes towards kingship. How far kings themselves were influenced is a question he leaves unanswered, but points to the introduction of sütras featuring King Aśoka (r. ca. 268-232 вСЕ) in the late fourth century as a body of work that deserves more attention (more on this below) in the quest for the ideological foundations of Buddhist kingship.

Leaving aside the question of which texts were crucial and how they inspired Chinese rulers, it is clear that the image of the cakravartin had a strong appeal. However, Palumbo notes that the cakravartin in fact initially served to emphasize the distance between the Buddha (and by extension monks) and such grand mythical rulers of the past, and did not serve as a model to be imitated. He is of course talking about the early phase of Buddhism in China (up to ca. $400 \mathrm{CE}$ ). In later periods, the cakravartin was invoked by Chinese rulers (and those of Silla ( 57 BCE-668 CE, 新羅) as well), but Palumbo's work does point to the fact that a term like 'cakravartin' was not well understood, or was understood very differently depending on time and place. Thus, while the image of the cakravartin's power may be inspiring, it is hardly an ideological statement. There are certainly elements in cakravartin stories that can be attractive to rulers, but we should be careful in assuming any a priori ideology resting there. Unfortunately, all too often a direct link has been assumed between certain ideas in Buddhist texts and political reality. This is clear from the following quotation:

The cosmic Buddha Vairochana was the focus of Chinese tantric devotions in the Tang dynasty. He dominates the Avatamsaka Sutra (Ch. Hwayan jing) and many of the major esoteric texts [...].

The benefits Vairochana promised were both spiritual and political, and his usefulness in preserving imperial legitimacy was quickly recognized.

18 Antonello Palumbo, "Models of Buddhist Kingship in Early Medieval China," in Zhonggu shidai de liyi, zongjiao yu zhidu 中古時代的禮儀、宗教與制度 [Ritual, Religion, and Institutions in the Mid-ancient Period], ed. Yu Xin 余欣 (Shanghai: Shanghai guji chubanshe, 2012), 288. Jülch ("Introduction," 11) cites exactly this same page but concludes from it that "[...] in the Indian Tradition the cakravartin ideal was not meant to be a tool in the legitimation of a ruler, [...].” This does not seem to be what Palumbo is arguing; rather, he concludes that there is not sufficient evidence on the Indian side to conclude whether Buddhist legitimation was actually employed by Indian rulers. 
Symbolized by the sun [...], Vairochana is the chakravartin (C. lunwang), the Wheel-turning King or Universal World Ruler, a role that had great appeal for the emperors of China from the Tang dynasty onward. Aside from the spiritual legitimacy the title chakravartin provided, it suggested an era of universal peace with the Chinese emperor at the heart of it. $^{19}$

Among the many problematic statements in this passage, the most glaring is arguably that Vairocana (Chin. Piluzhenafo 毘盧遮那佛) is also a cakravartin. While it is not appropriate to dismiss such evidence out of hand, ${ }^{20}$ it is potentially misleading, most of all because it is representative of a trend to point to Vairocana as a kind of unifying paradigm; the reasoning is that since Vairocana is the cosmic Buddha from which all other buddhas and bodhisattvas emanate, he would be attractive to rulers keen on implementing centralisation of their states. Especially in general overviews or works of a more popular nature, this view is often encountered. For example, in relation to the famous Vairocana statue in the Tōdai Monastery (東大寺) in the city of Nara, Richard Bowring writes:

The central figure of this vast text [i.e. the Avatamsaka sūtra] is Vairocana, who was the outcome of a movement to unify all buddhas under a single entity; as the ultimate transcendent buddha of Mahāyāna [...] he was a natural symbol for rulers to adopt. ${ }^{21}$

Arguably such views may have been influenced by the role Vairocana played in other Buddhisms. Notably in Tibet, Matthew Kapstein notes, "[...] the Tibetan imperial state came to be constituted, through a principle of homology, as the

19 Patricia Berger, "Preserving the Nation: The Political Uses of Tantric Art in China," in Latter Days of the Law. Images of Chinese Buddhism 850-1850, ed. Marsha Weidner (Lawrence: Spencer Museum of Art, 1994), 91.

20 Charles Orzech, for example, argues for the interchangeability of categories such as bodhisattva or cakravartin. He argues that key texts, such as the Scripture of the Humane Kings, embrace different temporal and spatial frameworks, which he calls dharmic and rupic; the former refers to the positional visionary apprehension of reality in trance, the latter to the personal idiom of inborn substances and their interaction. Thus, what may appear different from one perspective is the same from another perspective. Charles Orzech, Politics and Transcendent Wisdom. The Scripture for Humane Kings in the Creation ofChinese Buddhism (University Park, Pa.: The University of Pennsylvania Press, 1998), 42.

21 Richard Bowring, The Religious Traditions of Japan (Cambridge: Cambridge University Press, 2005), 85 . 
body and mandala of the Buddha Vairocana." ${ }^{22} \mathrm{He}$ also notes the spread of Indian-influenced imperial cults throughout Asia, mentioning especially Japanese Shingon (真言) Buddhism. However, while the Avatamsaka sūtra and belief centered on Vairocana were indeed influential in China and Japan in the eighth century, it should not automatically be assumed that there was a direct parallel between text and practice. Although Shōmu Tennō (r. 701-756, 聖武天 皇), who initiated the construction of Tōdai Monastery and its Vairocana statue, seems to have been identified with Vairocana, ${ }^{23}$ this seems to have depended on the context. Elsewhere the emperor refers to himself as a servant of the Buddha and seems to treat Vairocana merely as a kind of deity. ${ }^{24}$ In any case, there is no evidence that Huayan (華嚴) ideology was specifically employed to identify the ruler with Vairocana. This is even more conspicuous in the case of Wu Zetian (625-705, 武則天). Though we know that she was a fervent supporter of Huayan Buddhism (the Huayan patriarch Fazang (643-712, 法藏) is even said to have written the Jin shizi zhang 金師子章 [Treatise on the Golden Lion] (T. 1880.45) especially for her), and though her legitimating strategies are verywell documented, nowhere is there any hint of association with Vairocana. ${ }^{25}$

That does not mean that we can rule out the possibility altogether. There have indeed been cases where Buddhist monks advocated doctrinal tenets as panacea for unification; this was the case, for example, in late Koryŏ, where Ch'ont'ae (天台) monks wanted to advocate the Three in One (Chin. huisan guiyi 回三歸一) doctrine attributed to Zhiyi (538-597, 智顗) as conducive to political unification. ${ }^{26}$ But those claims were made ex post facto, and there is no evidence that they were ever propagated by emperors or kings in their quest for unification.

One of the works that has the best potential to be called a "fundamental political text" of Buddhism ${ }^{27}$ is the already-mentioned Scripture on the

22 Matthew T. Kapstein, The Tibetan Assimilation of Buddhism. Conversion, Contestation, and Memory (Oxford: Oxford University Press, 200o), 6o.

23 See Serge Elisséeff, "The Bommōkyō and the Great Buddha of the Tōdaiji," Harvard Journal of Asiatic Studies 1.1 (1936): 88. Strictly speaking the statue is not of Vairocana but of Rocana (Chin. Lushena 盧舍那).

24 Bowring, Religious Traditions, 91-92.

25 Aside from a statue of Vairocana at the Longmen (龍門) Caves believed to have been dedicated by her, there is absolutely no textual reference to Vairocana when it comes to legitimating issues. Fazang himself resorted to cakravartin imagery in praise of Wu Zetian. See Forte, Political Propaganda and Ideology, 212-213.

26 Sem Vermeersch, "Buddhism and Political Integration: Reflections on the Buddhist Summa of Wŏnhyo and Political Power," Acta Koreana 18.1 (2015): 96-117.

27 Here I borrow the expression from Berger, who calls the Scripture on the Humane Kings a "fundamental political text of Tantrism." Berger, "Preserving the Nation," 91. 
Humane Kings. Research shows that it is an apocryphal sūtra fabricated in China in the second half of the fifth century, more specifically, after 477 under the Northern Wei Dynasty. According to research by Charles Orzech, the Scripture on the Humane Kings emerged in the aftermath of the persecutions of Buddhism that took place around 445 . As the Northern Wei ruling elites sinified, Buddhism was marked as 'foreign,' and therefore to cleanse the body politic of its allegedly corrupt influence, it was proscribed. Influential monks such as Tanyao (fl. ca. 46o-48o, 量曜) managed to allay traditional fears of Buddhism as inimical to the state by turning it into 'an arm of the state.' Tanyao became the head of a samgha bureaucracy subservient to the state, while 'Buddha households' of slaves and forcefully relocated citizens showed that Buddhism could make an economic contribution to the state. ${ }^{28}$ The Scripture on Humane Kings, Orzech argues, emerged in reaction to this. It advocates the fundamental independence of the samgha by criticizing the establishment of registration of monks, the fact that they served as officials, and the fact that slaves and soldiers were treated as monks. However, while thus arguing for the independence of the samgha, at the same time it proposes the usefulness of Buddhism to the state by describing state-protective rites and prescribing how kings can be identified as cakravartin or bodhisattva. Also, and very importantly, it defuses the charge of the 'foreignness' of Buddhism by collapsing the boundaries between 'foreign' and 'native' by making key concepts exchangeable. Most crucially, there is the fundamental identification between the Chinese/Confucian concept of humanity (Chin. ren 仁) and the foreign/Buddhist concept of forbearance (Chin. ren 忍), which are also homonymous in Chinese. ${ }^{29}$

Orzech's work remains the most important text for the study of Buddhist legitimation strategies in East Asia and deserves better recognition. ${ }^{30}$ Nevertheless, to carry the debate forward, it should also be recognized that his work is limited to the intellectual universe presented by the text itself; it is an exemplary study of the text in its intellectual context, yet it is not a historical study of how the text was put into practice. In other words, no matter how brilliant and revolutionary the text may be, if it does not inspire or inform actual legiti-

28 Orzech, Politics and Transcendent Wisdom, 113, 120.

29 Ibid. Here, I summarise his work, mainly with reference to Chapter 4, "The End of the Teaching and the Creation of Chinese Buddhism," 112-121, 124.

3o Jülch, "Introduction," for example, does not even mention him. Note also some of the reviews, which seem puzzled by the theoretical framework: see notably those by John McRae,"Politics and Transcendent Wisdom: The Scripture for Humane Kings in the Creation of Chinese Buddhism," Journal of Chinese Religions 27.1 (1999): 113-121, notably p. 116; and Steven Collins, "Orzech, Charles D. Politics and Transcendent Wisdom: The Scripture for Humane Kings in the Creation of Chinese Buddhism." The Journal of Religion 79.4 (1999): 698-700. 
mation strategies, then it becomes irrelevant. Whether or not this is the case is, however, difficult to ascertain; it remained relevant, and the very fact that it was 'retranslated' by Amoghavajra (705-774, Chin. Bukong 不空), who reinvented the scripture as an Esoteric Buddhist text, in 765 , shows that it mattered. However, we do not really know where the wishes of the monks behind the texts end and the reality of courtly politics took over. Was it the monks who deemed it relevant for their agenda or the kings? Or a combination? We know that Tang Daizong (r. 762-779, 唐代宗) ordered the Baigaozuohui 百高座會 [Hundred Seat Ritual] (the nation-protecting rite outlined in the scripture) held so as to repel invaders and obtain rainfall, and at this occasion also ordered the retranslation of the scripture. ${ }^{31}$ But it is also well known that Tang emperors favored Daoism over Buddhism, and a lot of the documents quoted by Orzech are, as he admits, a kind of Esoteric Buddhist apologia to convince Emperor Dezong (r. 779-805, 唐德宗; more lukewarm to Buddhism than his predecessor) to continue his sponsorship of Buddhism. ${ }^{32}$

Orzech's interpretation of the scripture seems to hinge on a blurring of boundaries between kings and buddhas; especially in the Esoteric Buddhist retranslation, the monk holding the ritual and the king were almost exchangeable; the Esoteric master was both "world renouncer" and "world conqueror."33 This would however imply that the monk could appropriate secular authority, for the world conqueror epithet is usually reserved for a king. However, elsewhere he notes that:

At once the servant of the imperial court and a cosmic sovereign, $\mathrm{Pu}-$ k'ung skillfully applied the recursive vision of the cosmos to the role of the ācārya. As we shall see from his correspondence, Pu-k'ung regarded himself as a servant to the Confucian sage-king. Yet he also considered himself the counterpart to the cakravartin, and in his ritual roles, he often functioned not only as Prajñāpāramitā bodhisattva, the Teacher, but also as Acalavajra, the protector. Thus while serving the transformative ends of the sage king, Pu-k'ung was in some sense the manipulator of and even the origin of those transformations. ${ }^{34}$

$31 \quad$ Orzech, Politics and Transcendent Wisdom, 16o.

32 Ibid., 202-203; See Stanley Weinstein, Buddhism under the T'ang (Cambridge: Cambridge University Press, 1987), 57-59 and 77-99 for a good overview of the position of the late Tang emperors Suzong (r. $75^{6-762}$, 唐肅宗), Daizong, and Dezong. Weinstein notes that esoteric monks like Amoghavajra did play a key part in the latter years of Tang Xuanzong's (r. 712-756, 唐玄宗) reign and during the reigns of Suzong and Daizong.

33 Orzech, Politics and Transcendent Wisdom, 167, 194.

34 Ibid., 191. 
I would characterize this as a model of mutual dependence, not one where differences are suspended. Indeed, some emperors seem to have even rejected the sütra altogether, probably because it collapses the boundaries between king and teacher. Liang Wudi (r. 502-549, 梁武帝) rejected the scripture as spurious, and Orzech dedicates a whole section of Chapter 3 to address his doubts, as if he has taken upon himself the task of convincing the emperor of the value of the scripture. But as the author admits, "He may also have balked at the status and role assigned by the scripture to kings." ${ }^{35}$ Indeed! As one of the most famous Buddhist monarchs in history, Liang Wudi pretty much decided for himself how he could arrogate Buddhism, and did not see any need for an ācārya (preceptor) or any other counterpart to validate his authority. This appears to be what Orzech calls a continuous cosmology, where buddhas and kings are of the same lineage, and hence a cakravartin will either become Buddha, or the cakravartin simply is the Buddha; in a discontinuous cosmology, cakravartin and Buddha are of different lineages. ${ }^{36}$ However, as some critics have pointed out, this is very much Orzech's theory, ${ }^{37}$ and it is not clear how kings appropriated this discourse or whether they understood it at all. Also, despite rejecting facile categorizations, he simply proposes a more sophisticated organization scheme. As I argue in my book, in the case of Koryŏ, kings seem to have depended much more on Buddhism than Chinese emperors. ${ }^{38}$ Even so, it is important to note that they invoked the Scripture on the Humane Kings mainly for its Entrustment (Chin. fuzhu 付囑) Chapter, i.e. the final chapter that entrusts the teaching to the king, because in the final age of the dharma monks can no longer be trusted to uphold it. This chapter thus can justify royal assertion of power or control over Buddhism. ${ }^{39}$

35 Orzech, Politics and Transcendent Wisdom, 83. Liang Wudi's doubts are noted simply in one line in the Buddhist catalogue Chu sanzang jiji 出三藏記集 [Collection of Notes Concerning the Provenance of the [Chinese] tripitaka], T. 2145.55, 54b. Tom De Rauw points out, however, that it was the passage that blames the demise of Buddhism on too much government control that was the main reason for his rejection of the sütra. See, Tom De Rauw, "Beyond Buddhist Apology. The Political Use of Buddhism by Emperor Wu of the Liang Dynasty (r. 502-549)" (PhD diss., Ghent University, 2008), 88.

36 Orzech, Politics and Transcendent Wisdom, 63.

37 See e.g. the review of Orzech's Politics and Transcendent Wisdom by McRae, "Politics and Transcendent Wisdom," 116.

38 Vermeersh, Power of the Buddhas, 144-145.

39 In China it was often invoked for this very reason. See e.g. the edict by Emperor Wen of Sui from 585, quoted by Falin 法琳 (572-640) in his Bian zheng lun 辯正論 [On adjudicating what is correct], T. 2110.52.509.a17-18. I am grateful to an anomymous reviewer for pointing me to this source. Although Koryŏ kings may have had the same ambition of subordinating Buddhism, this partial reading of the text never seems to have been 
Most poignantly, when it comes to the question of the relationship between dharma and kings, precedent is more important than scripture or doctrine. This is made abundantly clear in an important stele inscription dedicated to the first Koryo royal preceptor, Iŏm (870-936, 利嚴). In a dialogue with the Koryŏ founder, King T'aejo (r. 918-943, 太祖), he explains the categorical difference between kings and monks:

[T'aejo]: '[...] I learned about the Buddha's admonition [not to kill] a long time ago, and secretly embraced compassion. I am afraid that to deal with the remaining bandits, I will endanger many lives. You, master, did not regard 10,00o miles too much in order to convert the Three Han; to save the country, I hope for some good words.'

[Iŏm replied]: 'The Way is in the mind, not in external affairs. Dharma comes from oneself, not from others. Moreover, what the emperor practices and what the people practice are different. Although you raise an army and go on a campaign, it is for the benefit of the people. What is the reason [for saying] this? The royal sway takes [the area within] the four seas as his home, the myriad people as his children, and does not kill those who are innocent. As for punishing the evil in order to uphold good, this is universal salvation. ${ }^{40}$

Carved on a stele erected in 937, one year after the re-unification of the Korean peninsula by Koryŏ, and the first of eight remaining stele from T'aejo's reign, this is clearly a significant statement on the relation between king and others (including monks), where the king is clearly put in a category that is not directly beholden to Buddhism. Moreover, Iŏm's reply is also lifted verbatim from the biography of the Buddhist monk Gunavarman (367-431, 求那跋摩), from his encounter with Song Wendi (r. 424-452, 宋文帝) in 431, as described in the Gaoseng zhuan 高僧傳 [Biographies of Eminent Monks (of the Liang Dynasty)] ${ }^{41}$ Despite the availability of many Buddhist canonical texts to justify

successful in Koryŏ. See Sem Vermeersch, "Representation of the Ruler in Buddhist Inscriptions of Early Koryŏ" Korean Studies 26.2 (2002): 216-250.

“Kwangjo-sa Chinch'ŏl taesa pimyŏng 廣照寺眞澈大師碑銘 [Stele for the Great Master Chinch'ŏl from Kwangjo Temple]," by Ch'oe Ŏnwi 崔彦隲, Kyogam yŏkchuyŏktae kosŭng pimun 校勘譯註歷代高僧碑文 [Epigraphs of Eminent Monks, Edited with an Annotated Translation] 2, ed. Yi Chigwan 李智冠 (Seoul: Kasan mun'go, 1994), 21-22.

41 Gaoseng zhuan 高僧傳 [Biographies of Eminent Monks (of the Liang Dynasty)], T. 2059.50, 341a1-7. 
the relation between ruler and monk, we thus see that an idealised encounter from Chinese history is the main inspiration. ${ }^{42}$

Thus, when we talk about 'Buddhist ideology', in so far as it exists at all, it is important to acknowledge that we are talking about a sinified tradition that rested on precedent as much as on canonicity. Orzech in fact acknowledges the fact that Chinese models had a big impact on how Buddhism was conceived, ${ }^{43}$ but focuses mostly on "the clever use of linguistic similarity to underscore soteriological links." ${ }^{4}$ When the Scripture on the Humane Kings was retranslated in 765 , however, Amoghavajra got rid of some of the most obvious signs of its Chinese manufacture. For example, the mention of astral phenomena that were only relevant to the Chinese, such as lunar mansions, stars of the Three Dukes, the Southern and Northern Dipper, etc. ${ }^{45}$ In doing so, he accidentally highlighted the role that these played in the scripture's popularity. We still tend to focus too much on ideological schemes, whereas divination, sorcery, manipulation of omens, etc. may well have played a more important part in convincing people of the legitimacy of a ruler's reign. ${ }^{46}$

Nowhere is this better documented than in the case of Wu Zetian. Indeed, while her recourse to Buddhism to shore up her legitimacy as a female ruler has been well established, it has been too much seen as an exception to traditional patterns. Perhaps her biggest 'crime' is that the manipulation of signs and portents too clearly showed her hand. At least it left traces in the historic record, and this is our good fortune; more than for any other ruler in premodern East Asia, we have rich veins of documents that show various strategies and phases of the legitimation process. Perhaps it is true that as the first woman to reign in her own right as emperor, she went further than others, but still I do not think that any of her strategies were so exceptional after all.

42 Also, within China proper the conversion of Emperor Wen of Song was considered important enough to be taken up by the Buddhist apologete Falin (572-640, 法琳). See, Thomas Jülch, "In Defense of the Samgha: The Buddhist Apologetic Mission of the Early Tang Monk Falin," in The Middle Kingdom and the Dharma Wheel: Aspects of the Relationship between the Buddhist Samgha and the State in Chinese History, ed. Thomas Jülch (Leiden: Brill, 2016), 49 .

43 See Orzech, Politics and Transcendent Wisdom, 68: "[...] rather than being simply a reiteration of Buddhist ideas, the scripture represents a complex process of adaptation which resulted in a new 'Chinese' form of Buddhism." The best work on how Chinese models of thinking and reasoning reshaped Buddhism in China is still Robert Sharf, Coming to Terms with Chinese Buddhism. A Reading of the Treasure Store Treatise (Honolulu: University of Hawai'i Press, 2012).

44 Orzech, Politics and Transcendent Wisdom, 161.

45 Ibid., $162-163$.

46 As Moin points out, "astrology was as 'political' a science as history." Moin, The Millennial Sovereign, 11. 
Antonino Forte's study of one of the key documents in Wu Zetian's attempt to justify taking the throne remains the best starting point of any discussion of this problem. As is well known, the Mahāmeghasūtra ("The Great Cloud Sūtra," Dayun jing 大雲經, T. 387.12) contains a passage predicting the emergence of a female cakravartin. While this has long been regarded as an interpolation, i.e. a manipulation of the original text by inserting a passage tailor-made to an ideological program, Forte shows that this was in the original sütra, which can hence be regarded as a genuine translation produced in the fifth century. By contrast, he identifies the Dunhuang manuscript S. 6502, the Dayun jing Shenhuang shouji yishu 大雲經神皇授記義疏 [Commentary on the Meaning of the Prophecy about Shenhuang in the Great Cloud sütra], as a commentary on the Mahämeghasūtra, ${ }^{47}$ which makes it explicit that the female cakravartin referred to in the sütra is in fact Wu Zetian. What is particularly fascinating is that Forte can show who was involved in the process and contrast the cryptic and terse statements from official history with other documents that correct these often-misleading statements. The sūtra shows a broad consensus among the elite Buddhist samgha to push her as a legitimate thearch of a new dynasty, the Zhou Dynasty (690-705, 周), though with some restraint as well, for example in the identification with Maitreya. ${ }^{48}$

For the benefit of my own discussion of the general mechanisms of Buddhist legitimation in East Asia, I extract four points that are evident in Forte's work and backed up by other studies:

1. the active collaboration of the monastic community;

2. the all-out push to make the gold-wheel cakravartin the dominant mode of rulership, which was ultimately doomed;

3. the impact of the legitimation push outside the capital;

4. the use of symbols, relics, and portents, often borrowed from Daoism rather than Buddhism.

Regarding the first point, of course it should also be kept in mind that Wu Zetian herself had Buddhist grounding; she was also well-read, and may well have initiated some of the legitimating strategies. However, it is clear that many monks, even the ones we know as philosophers, such as Fazang or Wŏnch'ǔk (613-696, 圓測), ${ }^{49}$ were fully behind the project, and indeed, helped to shape it. As Chen Jinhua points out, in legitimation discourse it is often overlooked that the process benefits both sides: "[...] Buddhist monks adroitly availed

$47 \quad$ Forte, Political Propaganda, 69.

48 Summarizing from Forte, Political Propaganda, 189-243. Though the analysis is incisive and convincing, the way the argument is structured makes it difficult to extract anything like a clear-cut conclusion; it is simply too spread out to pinpoint precise page references. Ibid., 203. 
themselves of political power in promoting their religion." ${ }^{50}$ In other words, in return for their efforts at enhancing the position of the ruler, they fully expected their own legitimacy to be enhanced. In the volume The Middle Kingdom and the Dharma Wheel, chapters by Max Deeg and Albert Welter make clear the proactive approach taken by monks to mold the political actors to their agenda. Deeg shows how Xuanzang (6oo/6o2-664, 玄牀) seeks to influence Tang Taizong (r. 626-649, 唐太宗) by crafting stories in the record of his visit to India, the Datang xiyu ji 大唐西域記 [Records of the Western Regions of the Great Tang Dynasty], ${ }^{51}$ that are meant as a 'mirror' for him. Welter for his part shows how the monk Zanning (919-1001, 贊寧) sought to convince the court of Song Taizu (r. 96o-976, 宋太祖) that Buddhism was fully part of Chinese civilisation, and hence also part of the regular officialdom..$^{52}$

This brings us to the second point, namely the cakravartin ideal as the type of rulership most heavily pushed by the Buddhist community. Of course, this was not always successful, given that rulers may have preferred to remain aloof of Buddhism, or may have preferred other types of Buddhist legitimation. While at times, and this appears to have been the case in later dynasties such as Ming (1368-1644, 明) and Qing, the cakravartin ideal is simply paid lip service, at other times it was pushed as the main type of legitimation. This is notably the case under Wu Zetian, who was ascribed the position of a wheel turning king with the authority to rule not just China, but the whole of Jambudvippa. Indeed, her authority would put to shame even Chinese emperors of the Han Dynasty (206 вСЕ-220 CE, 漢). ${ }^{53}$ However, though during her reign many officials seem to have submitted to the discourse that made her into a cakravartin, "the conservative wing of Confucianism [...] reacted violently" during the last years of her reign, and thus "China did not become a theocracy of the Tibetan type." ${ }^{54}$ Despite the regular occurrence of references to the

50 Chen, Monks and Monarchs, 5 .

$51 \quad$ Max Deeg, "The Didactic Creation of an Indian Dynasty in the Xiyu ji," in The Middle Kingdom and the Dharma Wheel: Aspects of the Relationship between the Buddhist Sangha and the State in Chinese History, ed. Thomas Jülch (Leiden: Brill, 2016), 94-139.

$5^{2}$ Albert Welter, "Confucian Monks and Buddhist Junzi: Zanning's Topical Compendium of the Buddhist Clergy and the Politics of Buddhist Accommodation at the Song Court," in The Middle Kingdom and the Dharma Wheel: Aspects of the Relationship between the Buddhist Sangha and the State in Chinese History, ed. Thomas Jülch (Leiden: Brill, 2016), 222-277.

53 Eugene Y. Wang, Shaping the Lotus Sutra. Buddhist Visual Culture in Medieval China (Seattle: University of Washington Press, 2005), 125; also Forte, Political Propaganda, ch. 4, esp. 207.

54 Forte, Political Propaganda, 207. Presumably he refers to the fact that undue emphasis on the ruler as cakravartin would lead to a commensurate increase in the power of monks, who would be seen in the same lineage as kings. 
cakravartin, with the exception of Wu Zetian's Zhou dynasty, it would never be the mainstay of official legitimation discourse. Still, even if the Confucian literati were not convinced, that does not mean that the cakravartin rhetoric did not have an impact. Eugene Wang's study of the Saddharmapundarīkasūtra [Lotus sūtra] imagery shows how Wu Zetians's imagery spread to Dunhuang, where a 698 memorial stela speaks of "the thousand spokes of the golden wheel rolling on, as the Great Zhou [ruler] steers the cosmos." ${ }^{\text {"5 }}$ This and other examples show that the rhetoric was picked up across the empire, most likely because of the spread of key texts such as the Mahämeghasütra and its commentary, which was retrieved from Mogao Cave 17, a vast repository of manuscripts, books, and paintings all dating to before 10oo. This means that it must have been copied in Buddhist scriptoria in large numbers; but the Empress also seems to have taken to the new medium of printing to spread the message. The Raśmivimalaviśuddhaprabhānāmadhāraṇī (Chin. Wugou jingguang da tuoluoni jing 無垢淨光大陀羅尼經 [Immaculate Pure Light dhāran̄i sūtra, T. 1024]) was 'translated' in the waning years of her reign and spread through the medium of printing; it was already known in Korea in 706, i.e. the year of her death, yet probably came too late to shore up her authority. ${ }^{56}$

A fourth and final point to make is that, despite the preponderance of cakravartin rhetoric, ultimately what was most important was not so much a well-defined vision of authority as the manipulation of symbols. Long before she became empress, Wu Zetian was already working through various schemes to further her power. Thus in 652, her first son was named Li Hong (652-675, 李 弘), the name of a messianic ruler from Celestial Master Daoism (Chin. tianshidao 天師道), who was believed to emerge in times of chaos to save the world. ${ }^{57}$ Eugene Wang calls this "apocryphal prognostication,"58 and whether Daoist or Buddhist in nature, this appears to have been the overriding mechanism to convince the empire that it was her destiny to rule. Even the adoption of the famous 'Empress Wu characters' can be seen as an attempt to manipulate the cosmic order. Besides symbols, tactile expressions, especially relics, could also be used and manipulated as signs of 'divine' power to rule. Relics played a part as symbols of Buddhist power from the beginning, but were first rallied on an empire-wide scale under Sui Wendi, i.e. the famous renshou (仁壽) distribution of relics that took place from 601 to $604 .{ }^{59}$ The act of large-scale distribution

$55 \quad$ Wang, Shaping the Lotus Sutra, 126.

56 See T.H. Barrett, "Stūpa, Sūtra and Śarīra in China, C. 656-706 CE," Buddhist Studies Review 18.1 (2001): 1-64.

57 Wang, Shaping the Lotus Sutra, 233.

$5^{8}$ Ibid.

59 See Chen, Monks and Monarchs, 51-87. 
of relics is redolent of King Asoka, and as such can also be associated with cakravartin kingship. However, the physicality of relics, the miraculous properties invested in them, and their association with the 'true, uncorrupted body' of the Buddha are arguably more important than their association with the ideology of kingship. ${ }^{60}$

\section{Legitimation in Koryŏ}

In the case of Koryŏ, unfortunately we do not have such a rich body of primary sources to work from; in my 2008 study I therefore rely heavily on stele inscriptions, since they are practically the only contemporary sources. One of the key conclusions regarding the way they portray the king-Buddhism interface is that the former is almost never explicitly identified as either bodhisattva or cakravartin. The Entrustment Chapter of the Scripture on the Humane Kings is often invoked, with the king pledging 'outer protection' for monks, who are then entrusted with the 'inner protection' through mastery of Buddhist ritual and meditation. ${ }^{61}$ In other words, in Korea we seem to find a better realisation of what the Scripture on the Humane Kings sets out to achieve, a kind of balanced system of mutual dependence between king and high-ranking monks.

Given the hermeneutics of suspicion outlined in the previous sections, it would perhaps be best to see if we should not also subject this conclusion to more critical scrutiny. To try and achieve that I focus on a crisis-episode, because it throws up a lot of the issues and strategies discussed in the previous section. While the foundation of Koryŏ in 918 may have been the most crucial event in the creation of what I have termed a 'state Buddhist system,' the whole Koryo dynastic system was thrown into crisis with the enthronement of King Hyŏnjong (r. 1009-1031, 顯宗) in 1009. His predecessor Mokchong (r. 997-1009, 穆宗) had been removed and killed because of allegations that his mother had a relationship with someone else and wanted to create a new dynastic line through the child she had with him. Mokchong's removal was taken as a pretext by Koryŏ's suzerain, the Khitan Empire (907-1125, in Chinese sources known as Liao 遼), to launch a punitive expedition. The young king had to flee the capital, and to make matters worse, met with great enmity while making

6o See Eugene Y. Wang, "Of the True Body: The Famen Monastery Relics and Corporeal Transformation in Sui-Tang China," in Body and Face in Chinese Visual Culture, ed. Wu Hung and Katherine Tsiang (Cambridge: Harvard University Press, 2004), 79-118.

Vermeersch, Power of the Buddhas, 141-142. 
his way to the southern part of the country. There were even attempts on his life.

Thanks to a small group of loyal retainers, the country just barely survived, although it had to be practically rebuilt after the Khitan retreated, not so much because of economic damage, but because the dynastic system had been shaken to its core. Hyŏnjong had to accept greater influence from in-law familiessome of whom had assisted him during his flight—and moreover had to contend with continuing invasions from the Khitan.

While it is well known that Buddhist rituals, including Hundred Seat Rituals, were held during his reign to rally divine support against the invaders, I would like to focus on how the king used Buddhism to rally internal support. A key piece of direct evidence for events of the period is a colophon on an illuminated sūtra dated 1006; it is signed by Queen Dowager Hŏnae (964-1029, 獻哀, here identified with her honorific title Ǔngch’ŏn kyesŏng chŏngdŏk wangt’aehu 應 天啓聖靜德王太后), Mokchong's mother, yet next to her name is that of Kim Ch'iyang (d. 1009, 金致陽), known as her 'lover' with whom she had an illegitimate child. One year later, in 1007, a print was made of the Aryatathāgatādhișțānahrdayaguhyadhātukaraṇdamudrādhāranisūtra (T.1022A.19, 1022B.19). However, the colophon simply notes that it was made by a monk at Ch'ongji Temple (摠持寺), an important temple in the Koryŏ capital Kaesŏng that belonged to the Esoteric Ch'ongji School (摠持宗). Some have argued that the printing of this dhärañi sūtra was undertaken by those opposing the usurpation of power by the queen, but this is mere speculaton. ${ }^{62}$ We may just as well speculate that some of the same factors were at play here as in the case of Empress $\mathrm{Wu}$, namely the rallying of various Buddhist scriptural resources to prop up a female ruler. However, with much more modest aspirations than in China, Queen Hŏnae simply takes the title of 'disciple who has taken the bodhisattva precepts' (Posalgye cheja 菩薩戒弟子). ${ }^{63}$

Having gained the throne, Hyŏnjong seems to have done much the same thing, i.e. used Buddhist texts to strengthen his own legitimacy. It is even possible that his decision to start carving the blocks of what is now called the

62 Kwak Sŭnghun 郭丞勳, “Koryŏ chŏn'gi ‘Ilch'e yŏrae sim pimil chŏnsin sari pohyŏb’in t'aranigyŏng' ŭi kanhaeng 고려전기 '一切如來心秘密全身舍利寶箥印陀羅尼經” 의 간행 [Publication of the Precious Casket Seal dhārañ sūtra of the Secret Whole Body Relics of all tathāgatha Minds in Early Koryŏ], Asia munhwa 아시아문 화 [Asian Culture] 12 (1996): 134-135. For more on the background of this text, see Sem Vermeersch, "Beyond Printing: Looking at the Use and East Asian Context of Dhārānī Sūtras in Medieval Korea," Chonggyohakyŏn'gu 宗敎學研究 [Journal of religious studies] 34 (2016): 1-33.

63 Han'guk sangdae komunsŏ charyo chipsŏng 韓國上代古文書資料集成 [Collection of Documents from Korea's Earliest History], ed. Yi Kibaek 李基白 (Seoul: Ilchisa, 1993), 43. 
Koryŏ Taejanggyŏng 高麗大藏經 [tripițaka Koreana] was part of this undertaking. While conventional wisdom insists that it was done as part of a vow to drive away the Khitan invasions, as I tried to show previously, ${ }^{64}$ surely the project may have given him the chance to assert his authority across the country. Thus, the fact that a rare remaining print of the first Tripitaka (the blocks of which were burnt during the Mongol invasions of 1232) carries a handwritten vow for the long life of the king, may be taken as an indication that this strategy worked. ${ }^{65}$ The best window into the project of how he rebuilt his legitimacy remains, however, the stele of Hyŏnhwa Temple (玄化寺).

Hyŏnhwa Temple was built in 1021-1022 as a memorial temple to Hyŏnjong's parents, who had died in tragic circumstances. His mother, widow of King Kyŏngjong (r. 975-998, 景宗), eloped with a son of the founding king; when the affair was discovered by the then-reigning King Sŏngjong (r. 981-999, 成宗), they were banished and died early. Sŏngjong took care of the infant Hyŏnjong, but when Mokchong came to the throne, he was sent away to a Buddhist monastery. The stele erected at Hyŏnhwa Temple still remains and shows how Hyŏnjong tried to rewrite history: his parents died of illness but were otherwise exemplary! The inscription focuses on filial piety, which is represented as the source of both Buddhism and Confucianism. The king (Hyŏnjong) is represented as exemplary in this regard, and as deriving his status from past karma and the protection of gods, but no mention is made of either cakravartin or bodhisattva status. As the result of his pious actions, Buddhist relics manifested themselves miraculously, while the Chinese emperor is moved to grant copies of the tripitaka. Once the temple is completed, the king then undertakes many other projects, including the carving of printing blocks for four sūtras, including the Prajñāpāramitāsūtra (T. 220.5-7); this may be regarded as the beginning of the first tripitaka Koreana.

Thus, we see some of the familiar themes that were also in evidence in China, yet everything appears to be much more muted and less spectacular in our Korean case. Practically no clear reference to the cakravartin is made, ${ }^{66}$ while

64 See Sem Vermeersch, "Royal Ancestor Worship and Buddhist Politics: The Hyŏnhwa-sa Stele and the Origins of the First Koryŏ Tripitaka," Journal of Korean Studies 18.1 (2013): $115-146$.

65 See Kwŏn Hŭigyŏng 權喜耕, “Tongjang-sa sojang ŭi kamji kŭmja 'Pulsŏl Mirŭk sŏngbulgyŏng' e kwanhan ilkoch'al 東長寺所藏의 紺紙金字'佛說彌勒成佛經’에 관한 一考察 [A Study of the Purple-paper Gold-letter Scripture of Maitreya Becoming Buddha Kept at Tōchō Monastery]," Kogo misul 考古美術 [Art and Archeology] 165 (1985): 32.

66 While the term cakravartin occasionally occurs in the sources, mostly it is not used explicitly with reference to a Koryŏ ruler. For example, the stele of the famous monk Ǔich'ŏn (1055-1101), son of King Munjong, contains the phrase "you relinquished the cakravartin throne;" however, this sentence was uttered by a Chinese monk and addressed to Ǔich'ŏn 
monks are accorded the same 'honorific gap' in inscriptions as kings. Earlier I speculated that the cakravartin paradigm was still influential yet less explicit in official sources such as stele inscriptions. ${ }^{67}$ However, such explanation gives too much credit to an ideological framework that may have been no longer valid. In votive inscriptions by kings, the king always self-identifies as a "disciple having received the bodhisattva precepts," starting from T'aejo's, "This bodhisattva [vows] ordainee [...] prostrates himself and seeks refuge [...]." ${ }^{\prime 6}$ This is confirmed by some of the very rare representations of T'aejo in art. Perhaps the most famous is the representation of T'aejo in a painting by No Yŏng (d.u., 魯英) dated 1307. On the front part of this small lacquer painting is an Amitābha painting, while the back shows Kșitigarbha in the foreground and Dharmodgata in the background. No Yŏng depicts himself prostrate as a small figure before Ksitigarbha, but on the back T'aejo (he is identified as such by a small cartouche) is seen prostrate before Dharmodgata, a bodhisattva believed to reside in Mt. Kŭmgang (金剛山). Documentary evidence shows that this is connected to a legend, wherein T'aejo seeks the deity's assistance for the complete unification of the Later Three Kingdoms. ${ }^{69}$

While the painting is open to many interpretations, ${ }^{70}$ it is completely in tune with other information that shows Koryŏ kings in a subordinate position vis-à-vis monks or buddhas. One of the few other depictions of kings from the Koryŏ era shows King Kongmin ( $r$. 1351-1374, 恭壂王) and his spouse sitting next to each other. Between them in a cartouche is written "They subordinate their

while he was travelling in China. Thus, it should be considered polite hyperbole towards someone who might have laid claim to the throne. See "Yŏngt'ongsa Taegak Kuksa pi 靈 通寺大覺國師碑 [Stele for State Preceptor of Great Enlightenment [i.e. Üich'ŏn] at Yŏngt'ong Monastery]," by Kim Pusik 金富軾, Kyogam yŏkchu Kosŭng pimun 校勘譯註 高僧碑文 [Epigraphs of Eminent Monks, Edited with an Annotated Translation] 4, ed. Yi Chigwan 李智冠 (Seoul: Kasan munhwa, 1996), 120.

67 Vermeersch, Power of the Buddhas, 139 .

68 From the Prayer for the Hwaŏm dharma Assembly at Kaet'ae Temple. See "Sinsŏng wang ch'inje Kaet'aesa Hwaŏm pŏphoe so 神聖王親製開泰寺華嚴法會疏 [Exposition on the Hwaŏm dharma Assembly at Kaet'ae Monastery, Personally Authored by the Holy Sage King]," Tong'in chi mun sa yuk 東人之文四六 [Korean Writings in Four and Six [Character Lines]], Koryŏ myŏnghyŏn chip 高麗名賢集 [Collection of Eminent Scholars during the Koryŏ Dynasty] 5, ed. Ch'oe Hae 崔翡 (Seoul: Sŏnggyungwan taehakkyo ch'ulp'anbu, 1987), 89 .

69 Kungnip chungang pangmulgwan, Koryŏ Pulhwa taejŏn 高麗佛畫大展 [Grand Exhibition of Koryŏ Painting] (Seoul: Kungnip chung'ang pangmulgwan, 2010), 293.

70 See, e.g, Karen Hwang, "Transgression as Heaven's Mandate: Buddhist Iconography and Political Resistance in No Yŏng's Painting of 1307," in Transgression in Korea: Beyond Resistance and Control, ed. Juhn Young Ahn (Ann Arbor: University of Michigan Press, 2018), 21-52. 


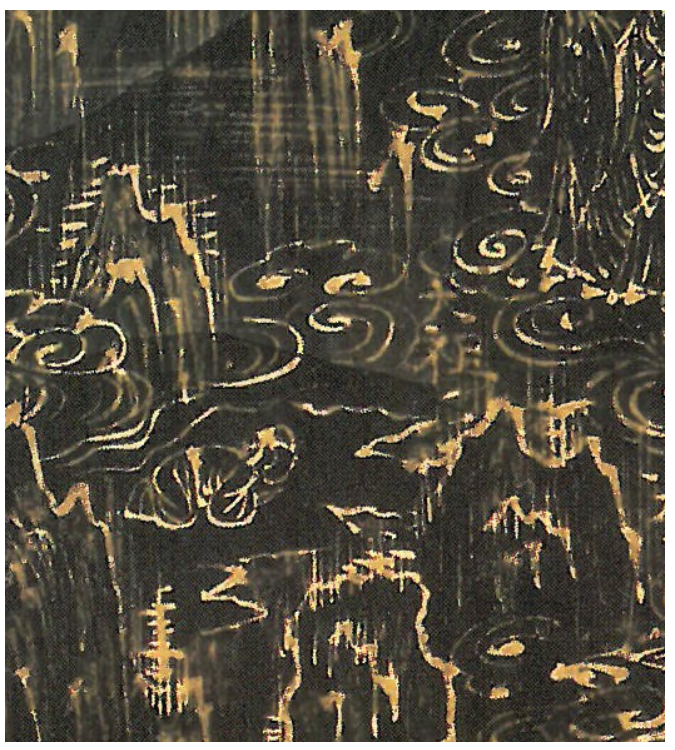

FIGURE 1.1

T'aejo worshipping Dharmodgata, Kaesŏng (?), 1307. Treasure no. 1887, National Museum of Korea. PHOTO COURTESY OF THE NATIONAL MUSEUM OF KOREA

minds." This is taken from the Vajracchedikāprajñāpāramitāsūtra and is related to the question Subhūti puts to the Buddha, namely on how to control ('subjugate') the mind so as to achieve awakening. ${ }^{71}$ While this may be taken to indicate that the king and queen are devout followers of the Buddha, it is not altogether clear why the phrase is placed between them. It may simply emphasize their devotion, yet it also seems to emphasize their subordination to Buddhism. ${ }^{72}$

While initially I thought that this was basically in tune with the scheme put forward by the Scripture on the Humane Kings, i.e. that the rulers act as 'outside protectors' (Kor. oeho 外護) for Buddhism by simply supporting it and taking a symbolically subordinate position towards it, that is arguably too restrictive. For one, the comparative subordination towards spiritual power may have its roots in earlier conceptions of kingship in Korea; for instance, in Silla before unification in 668, kings were mostly chosen from among a number of lineages; there was no strong sense of a 'single dynastic line' superior to others, reducing the authority of kingship; while this authority of course fluctuated, it never seems to have asserted any claims to transcendent authority. More importantly, however, we have to be wary of explanations that point towards an

71 Vajracchedikāprajñāpāramitāsūtra (T. 235·7,748c.28ff).

72 This edition of the sütra was printed in Namwŏn in 1363. Designated National Treasure no. 696, it is now held at the Sung-Am Archives of Classical Literature. For an illustration, see Kim, Kumja Paik, Goryeo Dynasty: Korea's Age of Enlightenment, 918-1392 (San Francisco: Asian Art Museum, 2003), 134. 
underlying ideological program, be it Buddhist or native. As shown in the case of King Hyŏnjong, moments of crisis lead to intense outbursts of legitimating activities, where Buddhism becomes important precisely because of the external symbolics of power rather than for any ideological program that is put into practice.

\section{5}

\section{Conclusion}

Through the above discussion I hope to have made clear that there is no clearly traceable source or ideological program from which East Asian monarchs would draw to construct their image in a Buddhist fashion. Nevertheless, textual models, though often creatively interpreted, cannot be ignored altogether. Whenever an important model of Buddhist rulership is discussed, such as the cakravartin, it should always be analyzed in terms of not only the textual model, but also precedents, historical context, and archeological and art-historical evidence; in short, any kind of information that offers clues as to how historical actors interpreted a certain term and made it their own.

Unfortunately, this is frequently ignored; moreover, in many cases we simply lack enough data to answer these fundamental questions. Thus, we must keep going to back to the standard set by Forte's work on Empress Wu, which is exemplary in its reading of the material against the full historical and intellectual background of the time. Of course, this is also a unique case in which we are fortunate to have the right mix of sources that allow us to undertake such a fine-grained analysis. That Forte's work still stands is borne out by recent arthistorical and archeological work by Eugene Wang and others.

Thus, the study of Buddhism and politics in any of the myriad kingdoms of Central and East Asia in the premodern period should be cognizant of this work, all the more so because historical actors were also aware of the model of figures such as Wu Zetian. We know this in the case of Japan, where Nara (710794, 奈良) rulers were inspired by her in various ways. ${ }^{73}$ For the case of Koryŏ too, although it is more difficult to discern clear influences due to the paucity of the right type of source material, Chinese historical precedent is crucial in understanding the dynamics between rulers, samgha, and religious models of kingship. The founder of the dynasty fashioned his image through a judicious selection of passages from early Chinese texts; perhaps because of this, the Koryŏ model of kingship is closer to what Palumbo describes of the period

73 See e.g. Peter Kornicki, "The Hyakumantō Darani and the Origins of Printing in Eighthcentury Japan," International Journal of Asian Studies 9.1 (2012): 59-63. 
before 400 in China, where the ruler effectively leaned on Buddhist groups for ideological and symbolic support. But of course, here too, local historical factors played a part, and as the case of King Hyŏnjong shows, the trials of invasion and internal unrest forced him to strengthen this model, rallying Buddhist support (and through that popular support) through an extreme act of piety, namely the carving of the complete tripitaka on printing blocks. 